\title{
CASP8AP2 Gene
}

National Cancer Institute

\section{Source}

National Cancer Institute. CASP8AP2 Gene. NCI Thesaurus. Code C126617.

This gene is involved in apoptotic signaling. 